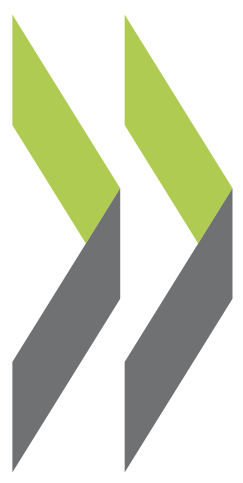

OECD Economics Department Working Papers No. 1186

A Constant Market Share Analysis of Spanish Goods Exports

\section{Alberto González Pandiella}


Organisation de Coopération et de Développement Économiques

Organisation for Economic Co-operation and Development

11-Feb-2015

ECONOMICS DEPARTMENT

English - Or. English

\section{A CONSTANT MARKET SHARE ANALYSIS OF SPANISH GOODS EXPORTS}

ECONOMICS DEPARTMENT WORKING PAPERS No. 1186

\section{By Alberto González Pandiella}

OECD Working Papers should not be reported as representing the official views of the OECD or of its member countries. The opinions expressed and arguments employed are those of the author(s).

Authorised for publication by Alvaro Pereira, Director, Country Studies Branch, Economics Department.

All Economics Department Working Papers are available through OECD's Internet website at http://www.oecd.org/eco/workingpapers

Complete document available on OLIS in its original format

This document and any map included herein are without prejudice to the status of or sovereignty over any territory, to the delimitation of international frontiers and boundaries and to the name of any territory, city or area. 
OECD Working Papers should not be reported as representing the official views of the OECD or of its member countries. The opinions expressed and arguments employed are those of the author(s).

Working Papers describe preliminary results or research in progress by the author(s) and are published to stimulate discussion on a broad range of issues on which the OECD works.

Comments on Working Papers are welcomed, and may be sent to the Economics Department, OECD, 2 rue André-Pascal, 75775 Paris Cedex 16, France, or by e-mail to eco.contact@oecd.org.

This document and any map included herein are without prejudice to the status of or sovereignty over any territory, to the delimitation of international frontiers and boundaries and to the name of any territory, city or area.

The statistical data for Israel are supplied by and under the responsibility of the relevant Israeli authorities. The use of such data by the OECD is without prejudice to the status of the Golan Heights, East Jerusalem and Israeli settlements in the West Bank under the terms of international law.

\section{(C) OECD (2015)}

You can copy, download or print OECD content for your own use, and you can include excerpts from OECD publications, databases and multimedia products in your own documents, presentations, blogs, websites and teaching materials, provided that suitable acknowledgment of OECD as source and copyright owner is given. All requests for commercial use and translation rights should be submitted to rights@oecd.org 


\section{ABSTRACT/RÉSUMÉ}

\section{A constant market share analysis of Spanish goods exports}

The constant market share analysis framework is used to decompose changes in Spain's share of the global market for goods exports into competitiveness and structural effects (i.e. the impact of specialisation, either in product or geographical terms) over 1996-2013. As other high-income countries, Spain has experienced competitive pressures from China and other emerging economies that have resulted in a loss of global market share. Nevertheless, the loss has been smaller than in other European advanced economies, thanks to better competitiveness. By contrast, the structure of geographic markets to which Spain exports, with a large-weight on relatively slow-growing areas and a small weight on fast-growing emerging countries, has exerted a negative impact on Spanish exports. In the same vein, the product structure, focused on relatively slow growing product lines, has not been conducive to better export performance either.

This Working Paper relates to the 2014 OECD Economic Survey of Spain (http://www.oecd.org/eco/surveys/economic-survey-spain.htm).

JEL classification: F14, F43, L6, O52

Keywords: Spain, exports, manufacturing, constant market share, competitiveness, market share effect, structure effect, trade specialization, technological content

$* * * * * * * * * * * * * * * * *$

\section{Une analyse des parts de marché constantes des exportations de biens espagnols}

Une analyse en parts de marché constantes est utilisé pour décomposer l'évolution de la part de l'Espagne du marché mondial de exportations de marchandises en deux facteur, la compétitivité et les effets structurels ( l'impact de spécialisation, soit en produit ou termes géographiques ), sur 1996-2013 . Comme d'autres pays à revenu élevé, l'Espagne a connu des pressions concurrentielles en provenance de Chine et d'autres économies émergentes qui ont abouti à une perte de part de marché mondiale. Néanmoins, la perte a été plus faible que dans les autres économies avancées européennes, grâce à une meilleure compétitivité. En revanche, la structure des marchés géographiques auxquels Espagne exporte, avec un grand poids sur les zones à croissance relativement lente et un petit poids sur les pays émergents à croissance rapide, a exercé un impact négatif sur les exportations espagnoles. Dans la même veine, la structure du produit, axée sur des gammes de produits de lente croissance, n'a pas été propice à une meilleure performance à l'exportation.

Ce Document de travail se rapporte à l'Étude économique de l'OCDE de l'Espagne, 2014 (http://www.oecd.org/fr/eco/etudes/etude-economique-espagne.htm).

Classification JEL : F14, F43, L6, O52

Mots clefs: Espagne, l'exportation, produits manufacturiers, les parts de marché constantes, la compétitivité, effet de part de marché, l'effet de la structure, la spécialisation du commerce, contenu technologique 
TABLE OF CONTENTS

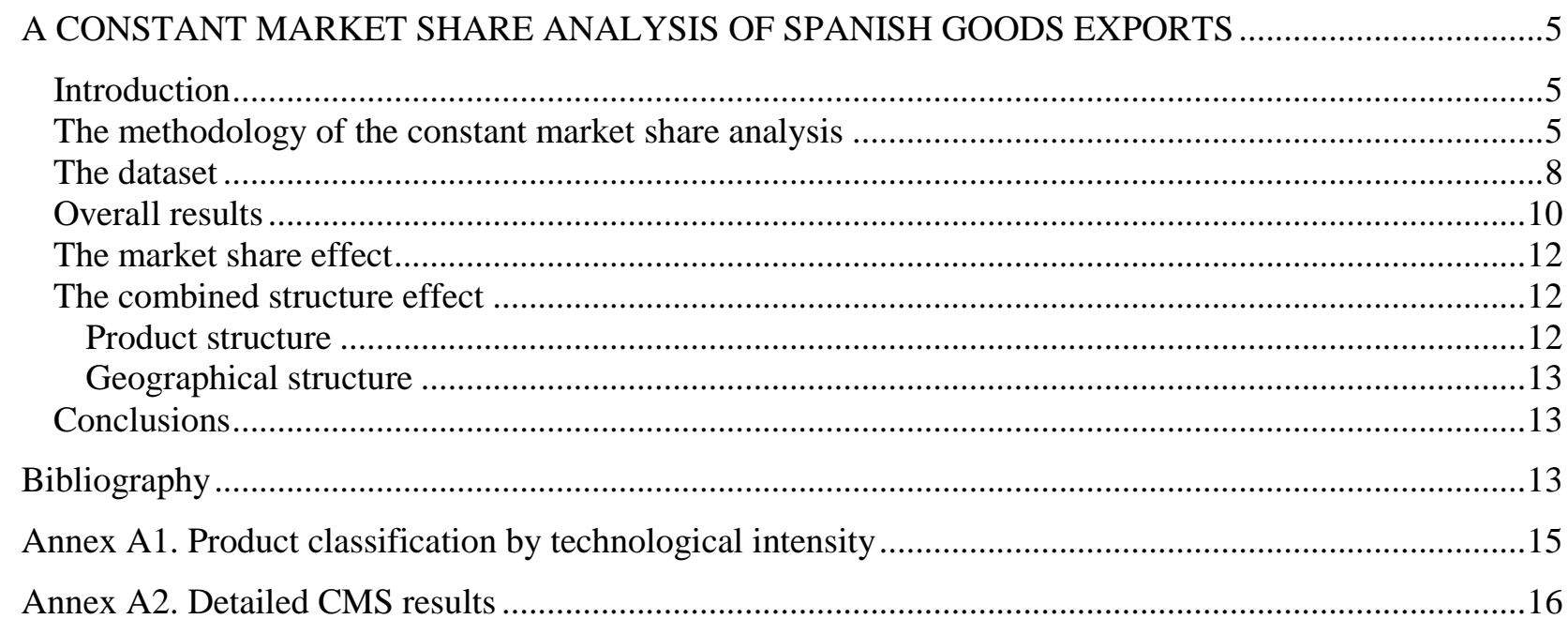

\section{Tables}

A2.1. Revealed comparative advantage of Spanish exports by industry and technology intensity.....16

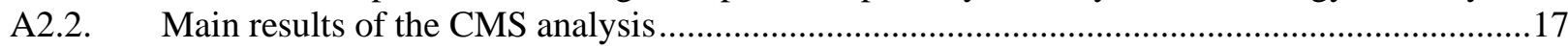

A2.3. Breakdown of market share effect by industry and technology intensity.................................18

A2.4. Breakdown of market share effect by partner country ..........................................................19

A2.5. Breakdown of the product structure effect by industry and technology intensity ....................21

A2.6. Breakdown of the geographical structure effect by partner country .......................................22

\section{Figures}

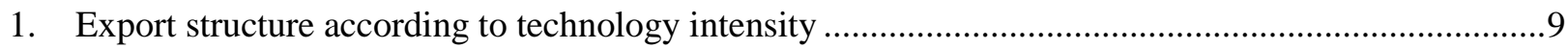

2. Main results of a constant market share analysis ............................................................................

3. Cross-country constant market share analysis results.....................................................................11 
ECO/WKP(2015)4

\title{
A CONSTANT MARKET SHARE ANALYSIS OF SPANISH GOODS EXPORTS
}

\author{
Alberto González Pandiella ${ }^{1}$
}

\section{Introduction}

Changes in a country's share of global export trade are a useful indicator of how well the economy can generate income to pay for imports. Changes in a country's market share in world exports can be influenced by many interrelated factors, such as competitiveness and specialisation. On the one hand, domestic and external macroeconomic features and developments can influence the relative competitiveness of exports, such as input costs or exchange rate changes, mark-up behaviour, and quality. On the other hand, structural factors, such as the endowment of productive factors or technology and geographical linkages, also condition the sectoral specialisation of exports and its distribution among different trading partners. Thus, if a country specialises in exports of goods (or towards areas) where demand is particularly buoyant, its aggregate market share will increase even if competitiveness does not improve. At the same time, even if a country maintains its share in individual markets, it can still have a decrease in its aggregate market share if the country is specialised in markets that grow more slowly than world exports or in products for which demand is growing more slowly than average. All these elements are relevant for the Spanish economy. While export performance has been better than in other high-income economies, the Spanish economy faces the challenge of sustaining and reinforcing its export performance to achieve further improvements in the current account balance and put external debt on a declining path.

This paper analyses the evolution of Spanish market shares in world exports over the period 1996-2013 taking into account the impact of sectoral and geographical composition on the aggregate results. It uses a constant market share (CMS) methodology as proposed by Nyssens and Poullet (1990). Other applications of CMS include ECB (2005), Amador and Cabral (2008), Skriner (2009), Pina (2011) and de Munnik et al. (2012).

The paper is structured as follows. The methodology of the CMS is described in Section I. Section II describes the dataset used. Section III presents the results of the CMS comparing the main results for Spain with those obtained for Germany, France and Italy. Section IV analyses the market share effect, while Section V concentrates on the structural effect. Last, Section VI presents some concluding remarks.

\section{The methodology of the constant market share analysis}

The CMS analysis is an arithmetic breakdown of the growth of a country's market share over a period of time into a structural component, reflecting the impact of specialisation by product and geographical area (the structure effect), and other factors reflecting changes in individual market shares (the market

1. Economist on the Spain/Ireland Desk at the OECD (Alberto.GonzalezPandiella@oecd.org). The author is grateful to Pierre Beynet, David Haugh, Sébastien Miroudot, Alvaro Pereira and Robert Ford for helpful comments and suggestions. Desney Erb provided excellent statistical support and programming. Thanks are also due to Sylvie Ricordeau and Krystel Rakotoarisoa for technical preparation. 
share or competitiveness effect). The starting point is the difference between a country's export growth and world export growth. When a country's export growth is higher (lower) than world export growth, that country is gaining (losing) world market share. Thus, following Nyssens and Poullet (1990) and Amador and Cabral (2008), the total change in the share of Spanish exports worldwide (the total effect, TE) is given by the difference between the growth rate of Spanish merchandise exports $(g)$ and the growth rate of world merchandise exports $(g *)$, that is:

$$
T E=g-g^{*}=\sum_{i} \sum_{j} \theta_{i j} g_{i j}-\sum_{i} \sum_{j} \theta_{i j}^{*} g_{i j}^{*}
$$

The notion of individual market used here refers to each $i j$ market measured as exports of product $i$ to destination country $j$.

Where $g_{i j}=\frac{X_{i j, t}-X_{i j, t-1}}{X_{i j, t-1}}$ is the percentage change of Spanish exports of product $i$ to country $j$ in period $t$, and $\theta_{i j}=\frac{X_{i j, t-1}}{\sum_{i} \sum_{j} X_{i j, t-1}}$ is the share of product $i$ to destination $j$ in total Spanish exports in period $t-1$, and $g_{i j}^{*}=\frac{X_{i j, t}^{*}-X_{i j, t-1}^{*}}{X_{i j, t-1}^{*}}$ and $\theta_{i j}^{*}=\frac{X_{i j, t-1}^{*}}{\sum_{i} \sum_{j} X_{i j, t-1}^{*}}$ are the equivalent terms for world exports (excluding Spain).

If the growth of Spanish exports is higher (lower) than that of world exports, the TE will be positive (negative), corresponding to a total market share gain (loss) of Spain. The TE can be broken down into two terms: one results from effective changes in market shares in individual markets, the so-called market share effect (MSE), which can be interpreted as an indicator of competitiveness; and another resulting from the influence of the relative specialisation of the country, the Combined Structure Effect (CSE). CSE comprises a product structure effect (PSE), a geographical structure effect (GSE) and a residual term (mixed structure effect, MIX).

$$
\mathrm{TE}=\mathrm{MSE}+\mathrm{CSE}=\mathrm{MSE}+\mathrm{PSE}+\mathrm{GSE}+\mathrm{MIX}
$$

The MSE is computed as the difference between the growth rate of Spanish and world exports in each period, excluding the influence of changes in relative specialisation as changes in export growth rates are weighted using the product share structure of the previous period. The MSE for a specific product $i$ (destination country $j$ ) can be taken as the sum over $j(i)$ of this effect.

$$
M S E=\sum_{i} \sum_{j} \theta_{i j}\left(g_{i j}-g_{i j}^{*}\right)
$$

By abstracting from changes in product and geographical structures, the MSE seeks to capture the extent to which changes in shares have been due only to changes in (price and non-price) competitiveness. Therefore the MSE is also commonly referred to as a competitiveness effect in CMS analysis.

The CSE captures the relative evolution of each individual destination market (defined as the difference between its growth and the growth of total world exports) weighted by the relative importance of that market for Spain (defined as the difference between its share in total Spanish exports and in total world exports). The CSE determines which part of the total change of market share results from the influence of the relative product/geographical specialisation of the country. In each period, the CSE will be positive if Spain is relatively more (less) specialised in individual markets that grow above (below) the 
average; the CSE will be negative if Spain is relatively less (more) specialised in individual markets that grow above (below) the average.

The CSE takes into account both the product and geographical specialisation of exports as a whole and can be decomposed further. The product structure effect (PSE) measures the contribution of Spain's product composition to changes in market share (i.e. to what extent the relative product specialisation of Spain is geared towards those more dynamic segments of world demand). It will be positive (negative) if Spain's composition of exports is more (less) concentrated in products growing above the world average. The geographical structure effect (GSE) measures the contribution of Spain's geographical export market composition. It will be positive (negative) if Spain's composition of exports is more (less) concentrated in geographical areas growing above the world average. The CSE also contains a residual term, so-called the mixed structure effect (MIX), which results from the fact that the product and geographical structures are not independent and thus the sum of the product and geographical effects does not match the combined structure effect.

$$
\begin{aligned}
& \text { CSE }=\text { PSE }+ \text { GSE }+ \text { MIX } \\
& P S E=\sum_{i}\left(\theta_{i}-\theta_{i}^{*}\right)\left(g_{i}^{*}-g^{*}\right) \\
& G S E=\sum_{j}\left(\theta_{j}-\theta_{j}^{*}\right)\left(g_{j}^{*}-g^{*}\right) \\
& M I X=\sum_{i} \sum_{j}\left[\left(\theta_{i j}-\theta_{i j}^{*}\right)-\left(\theta_{i}-\theta_{i}^{*}\right) \frac{\theta_{i j}^{*}}{\theta_{i}^{*}}-\left(\theta_{j}-\theta_{j}^{*}\right) \frac{\theta_{i j}^{*}}{\theta_{j}^{*}}\right] g_{i j}^{*}
\end{aligned}
$$

where:

$\theta_{i}=\sum_{j} \theta_{i j}$ (share of product $i$ in Spanish exports)

$\theta_{i}^{*}=\sum_{j} \theta_{i j}^{*}$ (share of product $i$ in world exports)

$\theta_{j}=\sum_{i} \theta_{i j}$ (share of market $j$ in Spanish exports)

$\theta_{j}^{*}=\sum_{i} \theta_{i j}^{*}$ (share of market $j$ in world exports)

$g_{i}^{*}=\frac{\sum_{j} \theta_{i j}^{*} g_{i j}^{*}}{\theta_{i}^{*}}$ (growth rate of world exports of product $i$ )

$g_{j}^{*}=\frac{\sum_{i} \theta_{i j}^{*} g_{i j}^{*}}{\theta_{j}^{*}}$ (growth rate of world exports to market $j$ )

The term $\theta_{i j}-\theta_{i j}^{*}$ provides information about the relative specialisation by comparing Spain's export structure with world export structure. It gives information equivalent to the traditional Balassa index of revealed comparative advantage (Balassa, 1965). 
This formulation incorporates some improvements over the traditional implementation of the CMS analysis to address some of the shortcomings found in earlier studies (Richardson 1971a, 1971b), as discussed in Amador and Cabral (2008). Some limitations remain though. For instance, CMS analysis results are sensitive to the degree of product and geographical disaggregation. Finer levels of disaggregation tend to result in larger structural effects and lower market share effects (Loveridge and Sterling, 1998).

\section{The dataset}

The data used comes from the OECD International Trade by Commodity Statistics database, which provides detailed annual nominal imports and exports goods data for OECD countries by commodity and partner country in term of values and expressed in US dollars. The use of annual data has the advantage of avoiding the volatility observed in higher frequency trade data. The data is based on the International Standard Industry Classification (ISIC) Revision 3 at the 2-digit level, which corresponds to 68 different products. The sectors covered are manufacturing (excluding energy) plus agriculture, forestry and fishing. To facilitate the analysis country results are presented on an individual basis for Spain's largest trading partners and aggregated by main regions.

Focussing on gross goods exports implies some limitations, in comparison with other datasets that include also trade in services or value added decompositions (Koopman et al., 2014 and Timmer et al., 2013). But it also offers some advantages such as exploiting a more comprehensives dataset in terms of bilateral trade relationships and, especially, being able to incorporate in the analysis more recent data.

Results are also presented according to the technological content of exports. Exports can be classified as having high, medium-high, medium-low or low technology content, based on the intensity of research and development (R\&D) invested (OECD, 2011; Annex A1). This classification is not without limitations. Some industries classified under the low-technology category may still cover some segments that incorporate high-technology activities (e.g. design in the textile industry). It nevertheless provides a broad picture of technological content that can serve as a useful dimension to assess export performance trends. More than $60 \%$ of manufacturing world trade takes place in medium-high and high technology goods. The share of medium-low technology exports is the segment with the largest increase in more recent periods (from about $14 \%$ in 1996 to $17 \%$ in 2012). By contrast, the share of low-technology goods in world exports has been falling since 1996. As a consequence, countries specialising in low-technology goods are facing weaker world demand for their products, with respect to those countries which specialise in more high-technology products.

In comparison with the structure of world exports, Spain's has a lower proportion of high-technology exports (Figure 1). The proportion of medium-high technology exports other than motor vehicles is also lower. By contrast, motor vehicles, within the medium-high segment, account for a substantial share of Spanish exports. Its share has been decreasing, although there was a small rise in 2013. As in world exports, the proportion of other medium technology goods in Spanish exports is increasing. Concerning low-technology products, its proportion in world exports fell until 2006, when it stabilised. This fall prior to 2006 was more muted in Spain than in world exports. As of 2008 the share of low-technology products in Spanish exports has increased. 
Figure 1. Export structure according to technology intensity

Proportion of total manufacturing ${ }^{1}$
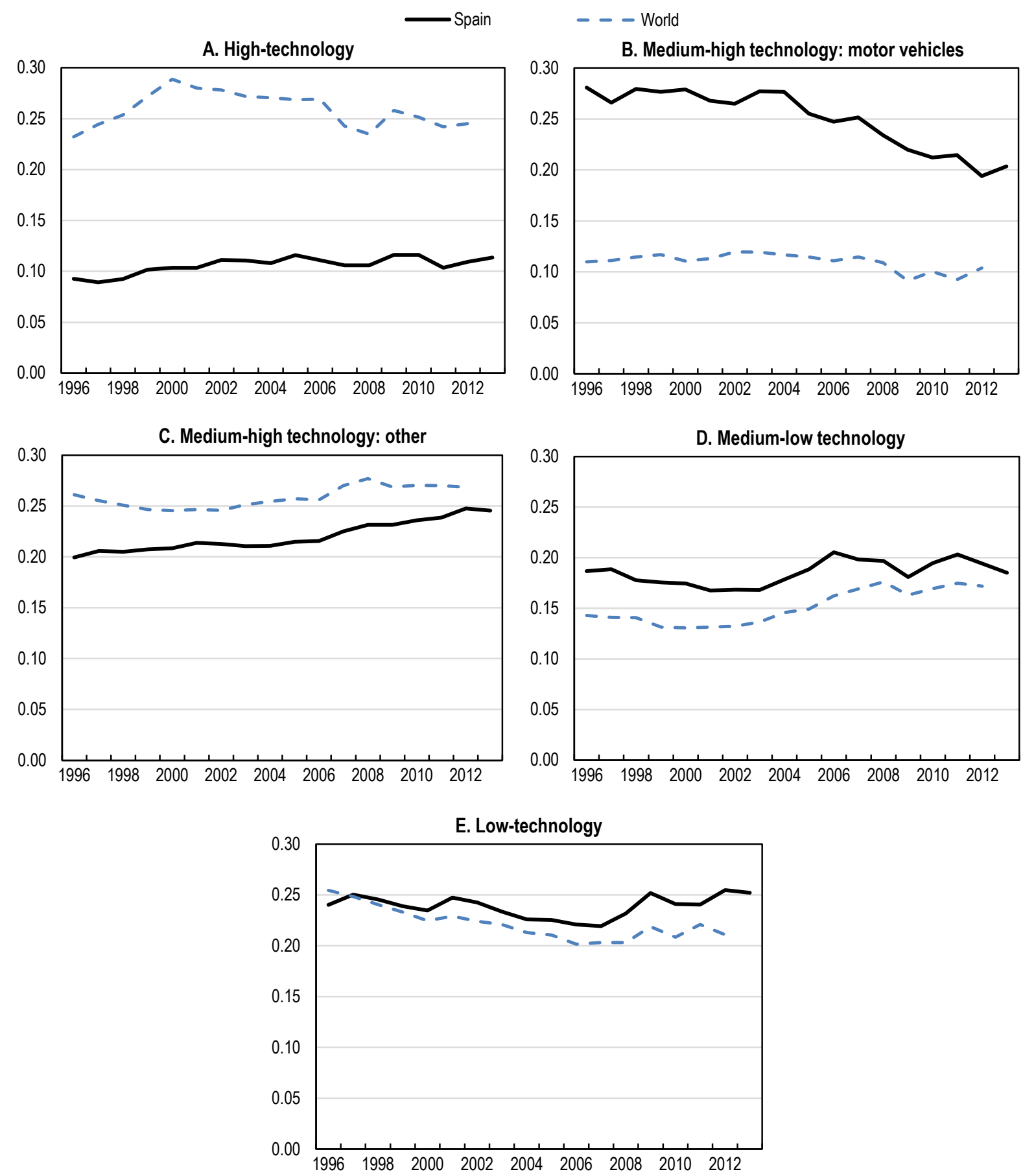

1. Based on exports in US dollars, nominal values. The sector covered is manufacturing (excluding energy).

Source: Calculations based on OECD (2014), International Trade by Commodity Statistics (ITCS Database), May. 


\section{Overall results}

While Spain's export growth was similar to world export growth in the period 1995-2007, it was below world growth in the period 2008-11, due to both negative competitiveness (as measured by the market share effect) and structural effects (Figure 2 below and Table A2.2). In 2012 Spanish export growth was above world export growth, driven both by competitiveness and product structure positive contributions. Overall, in the period 1995-2012, Spanish exports show a cumulative loss of total market share of about 20\% (Figure 3, Panel A). Competitiveness and geographical structure contributed to these losses, while product structure had a neutral contribution.

Figure 2. Main results of a constant market share analysis

Percentage points ${ }^{1}$
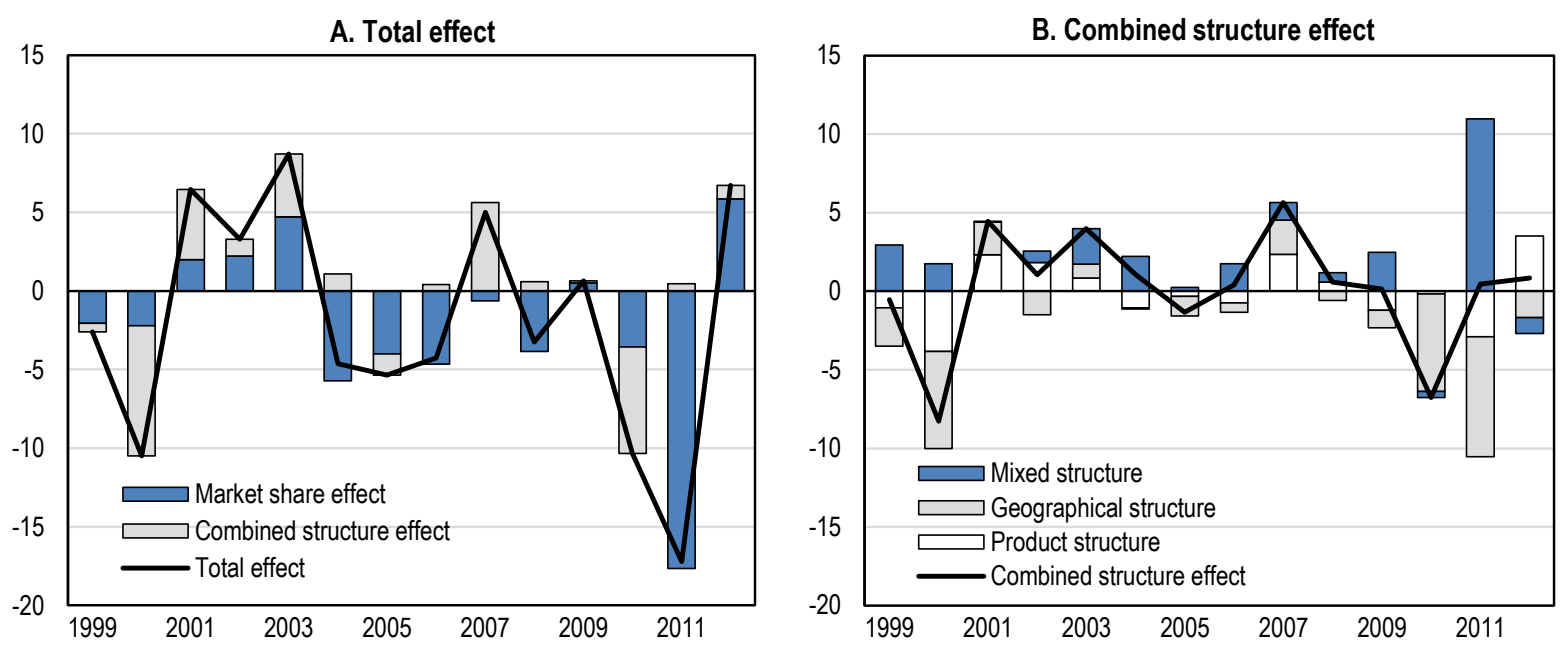

1. Based on exports in US dollars, nominal values. The sector covered is manufacturing (excluding energy) plus agriculture, forestry and fishing.

Source: Calculations based on OECD (2014), International Trade by Commodity Statistics (ITCS Database), May.

How to read this figure: Total effect is the difference between the growth rates of Spanish exports and of world exports. The market effect aggregates the variation of shares in individual export markets. The combined structure effect can be decomposed into product and geographical structure effect plus a residual term (so-called mixed effect). Product and geographical effects are positive if a country has above average specialisation in markets that grow faster than overall world trade. Conversely, high specialisation in slow-growing markets gives rise to negative structure effects.

A comparison with other advanced European economies, such as Germany, France and Italy, reveals that Spanish exports have been relatively resilient. Spanish export performance ${ }^{2}$ has been comparable to Germany's (Figure 3, Panel A), with France and Italy having larger cumulative losses of market share. Spanish competitiveness, as measured by the market share effect, has been relatively resilient when compared with the benchmark countries (Figure 3, Panel B). This is consistent with findings in Antras (2010), where the important role of firm heterogeneity in explaining Spanish export market share resilience is documented.

2. This paper compares exports growth in a given country with world exports growth when referring to export performance. Hence, export performance in this paper differs from other indicators of export performance such as the ratio of export volumes to export markets. A second difference is that this paper focuses on manufacturing goods while other export performance indicators include both goods and services exports. 
Figure 3. Cross-country constant market share analysis results ${ }^{1}$
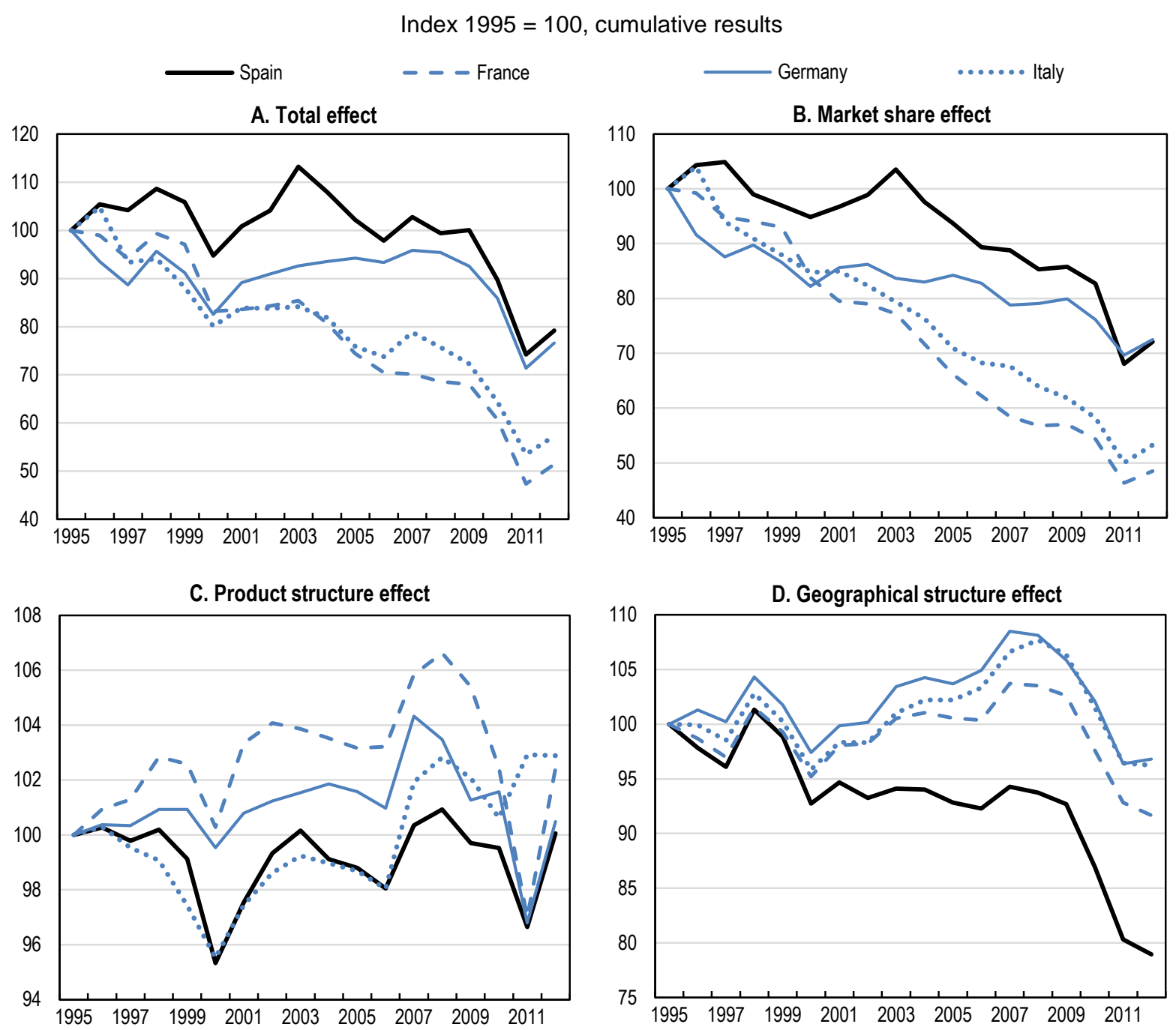

1. Based on exports in US dollars, nominal values. The sector covered is manufacturing (excluding energy) plus agriculture, forestry and fishing.

Source: Calculations based on OECD (2014), International Trade by Commodity Statistics (ITCS Database), May.

Comparing contributions of product and geographical structural also offers some insights. Product structure had a rising positive contribution to export performance in Germany and France (Figure 3, Panel C). Spanish and Italian exports product structures did not correspond to the products where world exports growth was more dynamic in the period 1995-2006. Nevertheless, as of 2006 Italy shifted its sectoral export structure towards more dynamics products, while Spain showed limited progress on that front. This is consistent with findings in Xifré (2014), where it is suggested that Italian exporting firms are more successful in climbing up global value-added chains. Concerning the evolution of the geographical structure effect, it has also been more favourable in Germany and Italy, and to a lesser extent France, than in Spain (Figure 3, Panel D).

Further insights concerning the relative specialisation of Spanish exports can be gained by looking at the "revealed comparative advantage" index, which is embedded within the CMS calculations (Table A2.1). This is calculated by dividing the share of a country's exports in a given industry by the share of that industry in world exports. Specialisation patterns generally tend to change very slowly and 
this is the case in Spain from 1996 to 2012. Specialisation has remained nearly unchanged, with only a small shift in specialisation from medium technology towards low-technology observed in more recent periods. Sluggish changes in specialisation have also been found in other European countries. For example, Germany has maintained its comparative advantage in medium-high technology goods and Italy in low to medium-high technology goods (ECB, 2013). Nevertheless, other countries such as Ireland have shifted towards higher-technology exports (ECB, 2013).

\section{The market share effect}

The MSE provides information about how trade shares have evolved, independently of structural developments in trade patterns. The results point to a small loss of market share in the period 1996-2001, followed by larger losses in 2002-07 and 2008-12 (Figure 3, Panel B). Given the detailed dataset used in the analysis, it is possible to provide an industry and product breakdown of these results (Table A2.3). For that it is useful to group products according to their technology intensity as referenced earlier.

In the period 1996-2001, the largest loss of market share occurred in medium-low technology industries, particularly "building and repairing of ships and boats". There was also a loss of market shares in high technology products, and this was partly offset by market share gains in the remaining sectors, mostly in low technology products such as "food products" and "textiles".

In the period 2002-07, market share losses were concentrated in medium-technology industries, notably in "motor vehicles" and "building and repairing of ships and boats". On the positive side, there was a small increase in the market share of "pharmaceuticals". In 2008-12, Spanish exports of "building and repairing of ships and boats" and "motor vehicles" also lost share in world markets. There were also losses of market share in high-technology products, while market shares in low-technology industries were preserved.

Turning to the analysis of the geographical destinations (Table A2.4), in the period 1996-2001, Spain gained market share in OECD countries, notably France and Portugal, although these gains were not large enough to compensate share losses in Africa, notably Algeria and Morocco, and in China and other nonOECD countries. The losses of market share in Germany and Portugal were the main geographical contributions to the market share effect in 2002-07, reflecting the increased competition that Spanish firms faced in the EU market from new players in world trade. In the same vein, in the period from 2008 to 2012, the largest losses in market share were in France and in other non-OECD European countries.

\section{The combined structure effect}

\section{Product structure}

This section identifies the individual products driving the evolution of the product structure effect. On average, during 1996-2012, the relative product specialisation of Spanish exports had a negative effect on export performance. The contribution of the product structure was negative in 1996-2001, positive in 2002-07 and neutral in 2008-12 (Table A2.5). In 1996-2001 the most negative effect came from the relatively low specialisation of Spanish exports in high technology products. World exports of these products grew above average, which contributed to negative product market effects across all hightechnology categories. This was partly offset by positive product market effect in some medium technology segments such as "motor vehicles" and "other machinery and equipment".

Conversely high-technology products had a positive contribution in 2002-07, stemming from "office, accounting and computing machinery". Spain is not specialised in these goods, so the fact that world exports of these goods grew well below average had a positive impact on the product effect. The opposite occurred in "other machinery and equipment" in the medium-technology industries. World exports of 
machinery rose strongly in 2007, which translated into a negative product effect due to the relative under specialisation of Spanish exports in this segment.

In the period 2008-12, the product structure had, overall, a neutral contribution to export performance. Nevertheless, some further insights can be obtained when looking at a more disaggregated product level. "Motor vehicles" grew below average resulting in a negative contribution to Spain's export performance. However, low technology products, in particular "food products" and "textiles" grew slightly above average. Given the relative over specialisation of Spanish exports in those segments, this translated into small positive product structure effects.

\section{Geographical structure}

The geographical specialisation of Spanish exports had an unfavourable impact on the overall evolution of market shares (Table A2.6). This reflects high relative specialisation of Spanish exports in some European markets and the below average growth rate of world exports to these countries. The main negative contributions were due to overspecialisation in France and Portugal over 1996-2012, and in Italy in 2007-12. Exports to the United States had a positive contribution over the period 2002-12, reflecting that the growth of world exports to the United States was below average in that period and that specialisation of Spain in that market is low. In contrast, the non-specialisation of Spanish exports in China and other Asian economies brought about important negative contributions, given the high growth of world exports to emerging Asian economies.

\section{Conclusions}

As other high-income economies, Spain has experienced competitive pressures from China and other emerging economies, for example in ship-building, that have resulted in a loss of global market share. The CMS analysis shows that these losses have been smaller in Spain than in other European advanced economies, thanks to better (price and non-price) competitiveness. Nevertheless, the structure of geographic markets to which Spain exports, with a large weight on relatively slow-growing areas, such as the Euro Area, and a small weight on fast-growing countries, such as China and other Asian economies, has exerted a negative impact on Spanish exports. The product structure, focused on relatively slow growing product lines, has not been conducive to better export performance either.

\section{BIBLIOGRAPHY}

Antras, P. (2010), "SERIEs Lecture at the 2010 Spanish Economic Association Annual Congress, Madrid, Spain," http://scholar.harvard.edu/files/antras/files/ponencia_sae_1.pdf

Amador, J. and S. Cabral (2008), "The Portuguese Export Performance in Perspective: A Constant Market Share Analysis", Banco de Portugal Economic Bulletin, Autumn 2008, pp. 201-221.

Balassa, B. (1965), "Trade Liberalization and "Revealed" Comparative Advantage", The Manchester School of Economic and Social Studies, Vol. 33(2), pp 99-123.

De Munnick, D., J. Jacob and W. Sze (2012), "The Evolution of Canada's Global Export Market Share", Bank of Canada Working Paper, 2012-31. 
ECB (2005), "Competitiveness and the Export Performance of the Euro Area", Occasional Paper Series, No. 30, Task Force of the Monetary Policy Committee of the European System of Central Banks, European Central Bank.

ECB (2013), "Country Adjustment in the Euro Area: Where Do We Stand", Monthly Bulletin, May, pp. 85-101.

Koopman, R., Z. Wang and S. Wei (2014), "Tracing Value-Added and Double Counting in Gross Exports," American Economic Review, American Economic Association, vol. 104(2), pages 459-94, February.

Loveridge, S.and A.C. Selting (1998), “A Review and Comparison of Shift Share Identities", International Regional Science Review, Vol. 21(1), pp. 37-58.

Nyssens, A. and G. Poullet (1990), "Parts de marché des producteurs de l’UEBL sur les marchés extérieurs et intérieur", Cahier 7, Banque Nationale de Belgique.

OECD (2011), "ISIC REV. 3 Technology Intensity Definition. Classification of Manufacturing Industries into Categories Based on R\&D Intensities", www.oecd.org/sti/ind/48350231.pdf.

Pina, Á. (2011), "Structural Reforms to Reduce Unemployment and Restore Competitiveness in Ireland", OECD Economics Department Working Papers, No. 910, OECD Publishing, http://dx.doi.org/10.1787/5kg0szws6t6c-en.

Richardson, J.D. (1971a), “Constant Market Shares Analysis of Export Growth”, Journal of International Economics, Vol. 1(2), pp. 227-239.

Richardson, J.D. (1971b), “Some Sensitivity Tests for a Constant Market Shares' Analysis of Export Growth", The Review of Economics and Statistics, Vol. 53(3), pp. 300-304.

Skriner, E. (2009), "Competitiveness and Specialisation of the Austrian Export Sector. A Constant-MarketShares Analysis", Economics Series, No. 235, Institute for Advanced Studies.

Timmer, M. P., B. Los, R. Stehrer and G. de Vries (2013). "Fragmentation, incomes and jobs: an analysis of European competitiveness," Working Paper Series 1615, European Central Bank.

Xifré, R (2014), “The Competitiveness of the Spanish Economy. A bird's-eye view of the four largest Eurozone economies", IESE WP-1088-E. 
ANNEX A1. PRODUCT CLASSIFICATION BY TECHNOLOGICAL INTENSITY

\begin{tabular}{|cc}
\hline \multicolumn{1}{c}{ Industry } & ISIC Revision 3 code \\
\hline TOTAL & $01-05,15-37$ excl. 23 \\
\hline Agriculture, forestry and fishing & $01+02+05$ \\
\hline Manufacturing & $15-37$ excl. 23 \\
\hline High-technology industries & 353 \\
\hline Aircraft and spacecraft & 2423 \\
\hline Pharmaceuticals & 30 \\
\hline Office, accounting and computing machinery & 32 \\
\hline Radio, TV and communications equipment & 33 \\
\hline Medical, precision and optical instruments & \\
\hline Medium-high-technology industries & 31 \\
\hline Other electrical machinery and apparatus & 34 \\
\hline Motor vehicles, trailers and semi-trailers & 24 excl. 2423 \\
\hline Chemicals excluding pharmaceuticals & $352+359$ \\
\hline Railroad equipment and other transport equipment & 29 \\
\hline Other machinery and equipment & \\
\hline Medium-low-technology industries & 351 \\
\hline Building and repairing of ships and boats & 25 \\
\hline Rubber and plastics products & 26 \\
\hline Other non-metallic mineral products & $27-28$ \\
\hline Basic metals and fabricated metal products & $36-37$ \\
\hline Low-technology industries & $20-22$ \\
\hline Other manufacturing and recycling & $15-16$ \\
\hline Wood, pulp, paper and printing products & $17-19$ \\
\hline Food products, beverages and tobacco & \\
\hline Textiles, textile products, leather and footwear & \\
\hline
\end{tabular}

Source: OECD (2011), "ISIC REV. 3 Technology Intensity Definition. Classification of Manufacturing Industries into Categories Based on R\&D Intensities", www.oecd.org/sti/ind/48350231.pdf. 


\section{ANNEX A2. DETAILED CMS RESULTS}

Table A2.1. Revealed comparative advantage of Spanish exports by industry and technology intensity

For each industry, share of Spanish exports divided by share of world exports (excluding Spain)

\begin{tabular}{|c|c|c|c|c|c|c|c|c|c|c|c|c|c|}
\hline & \multirow{2}{*}{2003} & \multirow{2}{*}{2004} & \multirow{2}{*}{2005} & \multirow{2}{*}{2006} & \multirow{2}{*}{2007} & \multirow{2}{*}{2008} & \multirow{2}{*}{2009} & \multirow{2}{*}{2010} & \multirow{2}{*}{2011} & \multirow{2}{*}{2012} & \multicolumn{3}{|c|}{ Average $^{1}$} \\
\hline & & & & & & & & & & & 1996-2001 & $2-07$ & $2008-12$ \\
\hline \multicolumn{14}{|l|}{ TOTAL } \\
\hline Agriculture, forestry and fishing & 2.4 & 2.3 & 2.3 & 2.2 & 2.0 & 1.9 & 2.0 & 1.9 & 1.8 & 1.8 & 2.2 & 2.3 & 1.9 \\
\hline Manufacturing ${ }^{2}$ & 1.0 & 1.0 & 1.0 & 1.0 & 1.0 & 1.0 & 1.0 & 1.0 & 1.0 & 1.0 & 1.0 & 1.0 & 1.0 \\
\hline High-technology industries & 0.4 & 0.4 & 0.4 & 0.4 & 0.4 & 0.4 & 0.4 & 0.4 & 0.4 & 0.4 & 0.4 & 0.4 & 0.4 \\
\hline Aircraft and spacecraft & 0.6 & 0.8 & 0.9 & 0.7 & 0.7 & 0.7 & 1.0 & 1.2 & 1.4 & 1.2 & 0.5 & 0.7 & 1.1 \\
\hline Pharmaceuticals & 0.9 & 0.9 & 1.1 & 1.1 & 1.2 & 1.2 & 1.1 & 1.2 & 1.4 & 1.4 & 0.8 & 1.0 & 1.3 \\
\hline Office, accounting and computing machinery & 0.2 & 0.2 & 0.1 & 0.1 & 0.1 & 0.1 & 0.1 & 0.1 & 0.1 & 0.1 & 0.2 & 0.1 & 0.1 \\
\hline Radio, TV and communications equipment & 0.3 & 0.3 & 0.3 & 0.3 & 0.2 & 0.2 & 0.2 & 0.2 & 0.1 & 0.1 & 0.3 & 0.3 & 0.2 \\
\hline Medical, precision and optical instruments & 0.3 & 0.3 & 0.3 & 0.3 & 0.3 & 0.3 & 0.3 & 0.3 & 0.3 & 0.3 & 0.3 & 0.3 & 0.3 \\
\hline Medium-high-technology industries & 1.3 & 1.3 & 1.2 & 1.2 & 1.2 & 1.2 & 1.2 & 1.2 & 1.2 & 1.2 & 1.3 & 1.2 & 1.2 \\
\hline Other electrical machinery and apparatus & 0.7 & 0.8 & 0.8 & 0.8 & 0.9 & 0.9 & 0.9 & 0.9 & 1.0 & 1.0 & 0.8 & 0.8 & 0.9 \\
\hline Motor vehicles, trailers and semi-trailers & 2.2 & 2.3 & 2.1 & 2.2 & 2.1 & 2.1 & 2.3 & 2.0 & 2.3 & 1.8 & 2.3 & 2.2 & 2.1 \\
\hline Chemicals excluding pharmaceuticals & 0.9 & 0.9 & 0.9 & 0.9 & 1.0 & 0.9 & 0.9 & 1.0 & 1.0 & 1.0 & 0.9 & 0.9 & 1.0 \\
\hline Railroad equipment and other transport equipment & 1.5 & 1.4 & 1.5 & 1.4 & 1.4 & 1.5 & 1.7 & 1.4 & 1.5 & 1.6 & 1.3 & 1.4 & 1.5 \\
\hline Other machinery and equipment & 0.7 & 0.7 & 0.7 & 0.7 & 0.6 & 0.6 & 0.6 & 0.6 & 0.6 & 0.7 & 0.7 & 0.7 & 0.6 \\
\hline Medium-low-technology industries & 1.2 & 1.2 & 1.2 & 1.2 & 1.1 & 1.1 & 1.1 & 1.1 & 1.1 & 1.1 & 1.3 & 1.2 & 1.1 \\
\hline Building and repairing of ships and boats & 1.4 & 1.9 & 2.5 & 2.8 & 1.2 & 0.3 & 0.6 & 0.6 & 0.5 & 0.3 & 1.2 & 1.8 & 0.4 \\
\hline Rubber and plastics products & 1.2 & 1.2 & 1.2 & 1.3 & 1.2 & 1.2 & 1.2 & 1.2 & 1.2 & 1.1 & 1.3 & 1.2 & 1.2 \\
\hline Other non-metallic mineral products & 2.4 & 2.3 & 2.3 & 2.3 & 2.3 & 2.2 & 2.1 & 2.1 & 1.9 & 2.1 & 2.5 & 2.4 & 2.1 \\
\hline Basic metals and fabricated metal products & 0.9 & 0.9 & 1.0 & 0.9 & 1.0 & 1.0 & 1.0 & 1.1 & 1.1 & 1.1 & 1.0 & 1.0 & 1.0 \\
\hline Low-technology industries & 1.0 & 1.0 & 1.0 & 1.1 & 1.0 & 1.1 & 1.1 & 1.1 & 1.1 & 1.2 & 1.0 & 1.0 & 1.1 \\
\hline Other manufacturing and recycling & 0.6 & 0.6 & 0.5 & 0.5 & 0.5 & 0.5 & 0.5 & 0.5 & 0.4 & 0.4 & 0.7 & 0.6 & 0.4 \\
\hline Wood, pulp, paper and printing products & 0.9 & 0.8 & 1.0 & 1.0 & 1.0 & 1.1 & 1.0 & 1.1 & 1.2 & 1.1 & 0.9 & 0.9 & 1.1 \\
\hline Food products, beverages and tobacco & 1.5 & 1.6 & 1.6 & 1.6 & 1.6 & 1.6 & 1.6 & 1.6 & 1.7 & 1.7 & 1.4 & 1.6 & 1.6 \\
\hline Textiles, textile products, leather and footwear & 0.8 & 0.8 & 0.8 & 0.9 & 0.9 & 1.0 & 1.1 & 1.0 & 0.9 & 1.1 & 0.8 & 0.9 & 1.0 \\
\hline
\end{tabular}

1. Simple average.

2. Energy related industries are excluded; they would generally be included with medium-low-technology industries.

Source: Calculations based on OECD (2014), International Trade by Commodity Statistics (ITCS Database), May. 
Table A2.2. Main results of the CMS analysis

Agriculture, forestry and fishing plus manufacturing sector (excluding energy), percentage points ${ }^{1}$

\begin{tabular}{|c|c|c|c|c|c|c|c|c|}
\hline & \multicolumn{2}{|c|}{ Growth of exports (\%) } & \multirow{2}{*}{ Total effect } & \multirow{2}{*}{$\begin{array}{c}\text { Market share } \\
\text { effect }\end{array}$} & \multirow{2}{*}{$\begin{array}{c}\text { Combined } \\
\text { structure } \\
\text { effect }\end{array}$} & \multicolumn{3}{|c|}{ Breakdown of combined structure effect } \\
\hline & Spain & World & & & & $\begin{array}{l}\text { Product } \\
\text { structure }\end{array}$ & $\begin{array}{l}\text { Geographical } \\
\text { structure }\end{array}$ & $\begin{array}{c}\text { Mixed } \\
\text { structure }\end{array}$ \\
\hline & 1 & 2 & $3=1-2=4+5$ & 4 & $5=6+7+8$ & 6 & 7 & 8 \\
\hline$\overline{1996}$ & 9.2 & 3.8 & 5.4 & 4.3 & 1.1 & 0.3 & -2.2 & 3.0 \\
\hline 1997 & 3.2 & 4.4 & -1.1 & 0.6 & -1.7 & -0.5 & -1.8 & 0.6 \\
\hline 1998 & 5.6 & 1.3 & 4.3 & -5.6 & 9.9 & 0.4 & 5.4 & 4.1 \\
\hline 1999 & 0.1 & 2.7 & -2.6 & -2.1 & -0.5 & -1.1 & -2.4 & 2.9 \\
\hline 2000 & -0.1 & 10.4 & -10.5 & -2.2 & -8.3 & -3.8 & -6.2 & 1.7 \\
\hline 2001 & 3.3 & -3.2 & 6.4 & 2.0 & 4.5 & 2.3 & 2.1 & 0.1 \\
\hline 2002 & 7.7 & 4.4 & 3.3 & 2.2 & 1.1 & 1.8 & -1.5 & 0.7 \\
\hline 2003 & 24.0 & 15.4 & 8.7 & 4.7 & 4.0 & 0.8 & 0.9 & 2.3 \\
\hline 2004 & 15.7 & 20.3 & -4.6 & -5.7 & 1.1 & -1.0 & -0.1 & 2.2 \\
\hline 2005 & 5.8 & 11.2 & -5.3 & -4.0 & -1.3 & -0.3 & -1.3 & 0.2 \\
\hline 2006 & 10.5 & 14.7 & -4.3 & -4.7 & 0.4 & -0.8 & -0.6 & 1.7 \\
\hline 2007 & 18.0 & 13.0 & 5.0 & -0.6 & 5.6 & 2.3 & 2.2 & 1.1 \\
\hline 2008 & 7.5 & 10.8 & -3.3 & -3.9 & 0.6 & 0.6 & -0.6 & 0.6 \\
\hline 2009 & -18.8 & -19.5 & 0.6 & 0.5 & 0.1 & -1.2 & -1.1 & 2.5 \\
\hline 2010 & 9.7 & 20.0 & -10.3 & -3.6 & -6.8 & -0.2 & -6.2 & -0.4 \\
\hline 2011 & 16.4 & 33.6 & -17.2 & -17.7 & 0.4 & -2.9 & -7.6 & 11.0 \\
\hline 2012 & -5.5 & -12.2 & 6.7 & 5.9 & 0.8 & 3.5 & -1.7 & -1.0 \\
\hline 2013 & 10.1 & . & $\ldots$ & $\ldots$ & $\ldots$ & $\ldots$ & $\ldots$ & $\ldots$ \\
\hline \multicolumn{9}{|l|}{ Average $^{2}$} \\
\hline $1996-2001$ & 3.5 & 3.2 & 0.3 & -0.5 & 0.8 & -0.4 & -0.8 & 2.1 \\
\hline $2002-07$ & 13.6 & 13.2 & 0.5 & -1.3 & 1.8 & 0.5 & -0.1 & 1.4 \\
\hline 2008-12 & 1.8 & 6.5 & -4.7 & -3.7 & -1.0 & 0.0 & -3.4 & 2.5 \\
\hline
\end{tabular}

1. Based on exports in US dollars, nominal values.

2. Simple average.

Source: Calculations based on OECD (2014), International Trade by Commodity Statistics (ITCS Database), May. 
Table A2.3. Breakdown of market share effect by industry and technology intensity

Percentage points

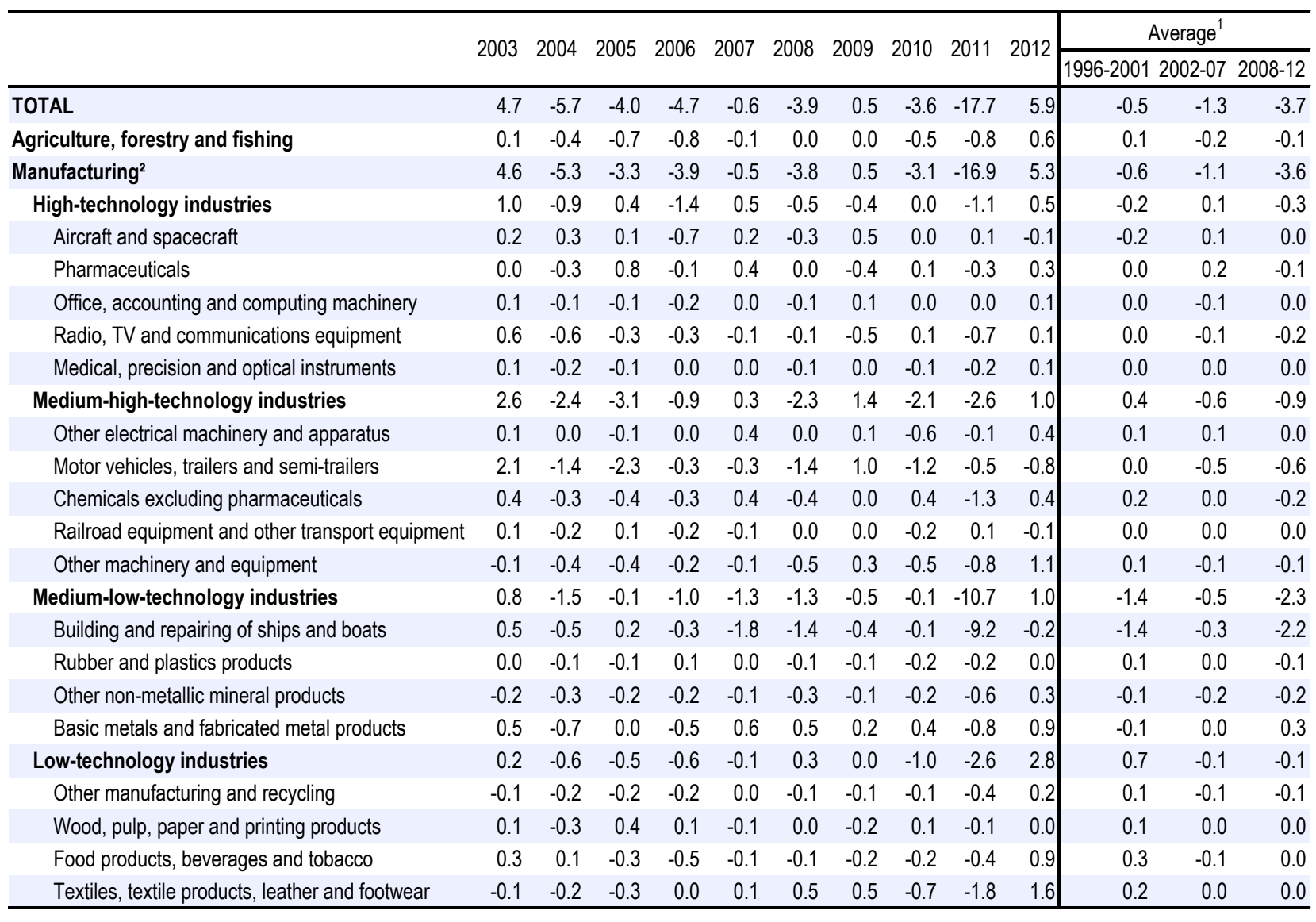

1. Simple average.

2. Energy related industries are excluded; they would generally be included with medium-low-technology industries.

Source: Calculations based on OECD (2014), International Trade by Commodity Statistics (ITCS Database), May. 
ECO/WKP(2015)4

Table A2.4. Breakdown of market share effect by partner country

Percentage points

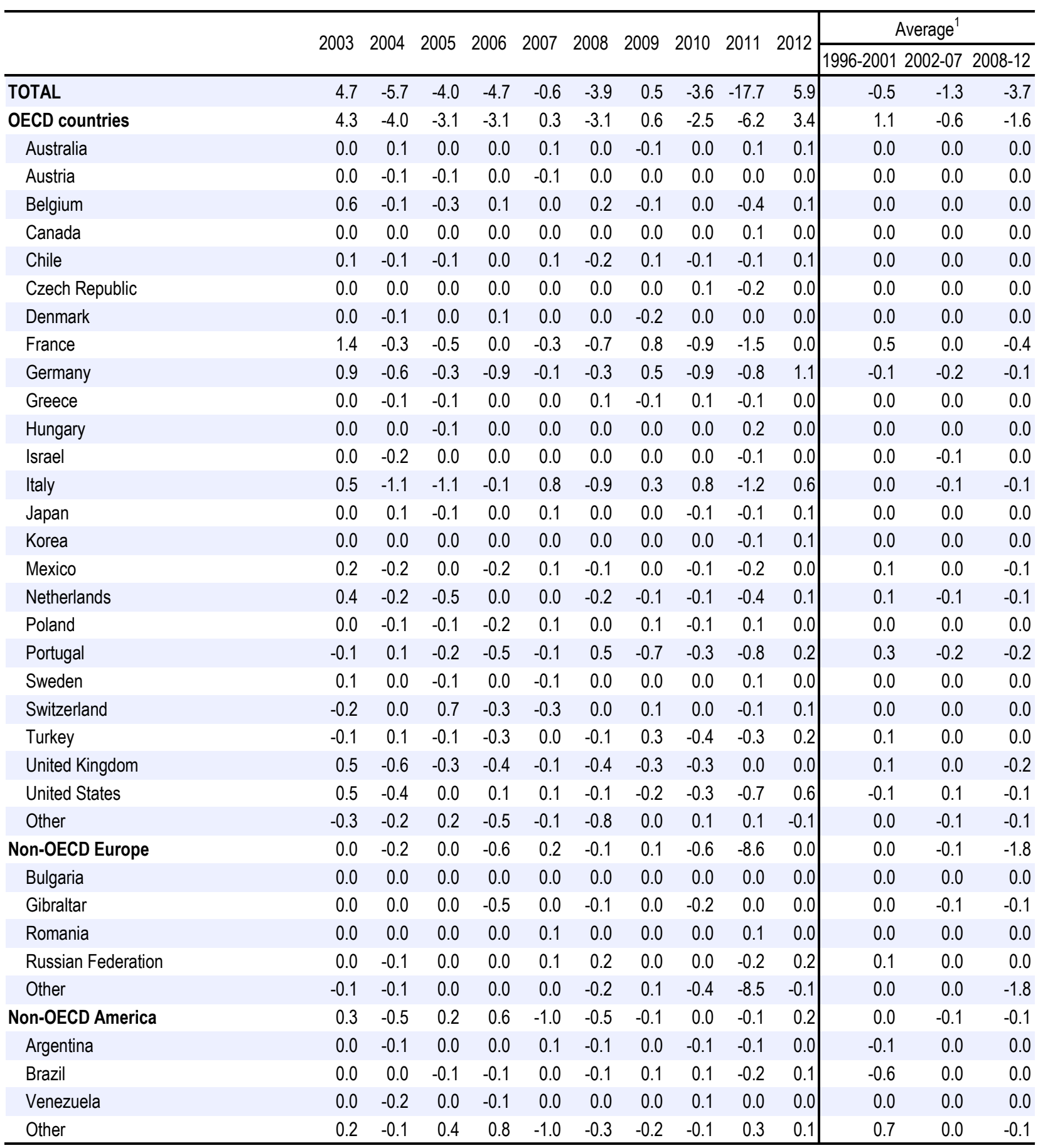


Table A2.4. Breakdown of market share effect by partner country (continued)

Percentage points

\begin{tabular}{|c|c|c|c|c|c|c|c|c|c|c|c|c|c|}
\hline & \multirow{2}{*}{2003} & \multirow{2}{*}{2004} & \multirow{2}{*}{2005} & \multirow{2}{*}{2006} & \multirow{2}{*}{2007} & \multirow{2}{*}{2008} & \multirow{2}{*}{2009} & \multirow{2}{*}{2010} & \multirow{2}{*}{2011} & \multirow{2}{*}{2012} & \multicolumn{3}{|c|}{ Average $^{1}$} \\
\hline & & & & & & & & & & & $1996-20012$ & $2-07$ & $2008-12$ \\
\hline Africa & 0.4 & -0.4 & 0.2 & -0.8 & -0.3 & 0.4 & 0.0 & -0.3 & -1.1 & 1.2 & -0.6 & -0.1 & 0.1 \\
\hline Algeria & 0.0 & -0.1 & 0.2 & -0.1 & -0.1 & 0.2 & -0.1 & -0.1 & 0.1 & 0.3 & -0.4 & 0.0 & 0.1 \\
\hline Egypt & 0.0 & 0.2 & -0.1 & -0.1 & 0.0 & 0.0 & 0.1 & 0.0 & -0.1 & 0.1 & 0.0 & 0.0 & 0.0 \\
\hline Morocco & 0.1 & 0.1 & -0.1 & -0.4 & -0.1 & 0.1 & 0.0 & -0.1 & -0.5 & 0.4 & -0.2 & 0.0 & 0.0 \\
\hline South Africa & 0.0 & 0.0 & 0.0 & 0.0 & 0.0 & -0.1 & 0.0 & 0.1 & -0.1 & 0.0 & 0.0 & 0.0 & 0.0 \\
\hline Tunisia & 0.0 & -0.1 & 0.0 & 0.0 & 0.0 & -0.1 & 0.0 & 0.0 & -0.1 & 0.0 & 0.0 & 0.0 & 0.0 \\
\hline Other & 0.2 & -0.5 & 0.1 & -0.2 & -0.1 & 0.2 & -0.1 & -0.1 & -0.3 & 0.4 & 0.0 & -0.1 & 0.0 \\
\hline Non-OECD Near and Middle East Asia & -0.1 & 0.1 & -0.9 & 0.0 & 0.2 & -0.1 & -0.2 & -0.1 & -0.3 & 0.5 & 0.0 & -0.1 & 0.0 \\
\hline Saudi Arabia & 0.0 & -0.1 & 0.0 & 0.0 & 0.1 & -0.1 & 0.0 & 0.0 & -0.1 & 0.1 & 0.0 & 0.0 & 0.0 \\
\hline United Arab Emirates & 0.0 & -0.1 & 0.0 & 0.0 & 0.0 & 0.1 & -0.1 & -0.1 & 0.0 & 0.1 & 0.0 & 0.0 & 0.0 \\
\hline Other & -0.1 & 0.2 & -0.9 & 0.0 & 0.1 & -0.1 & -0.1 & 0.0 & -0.1 & 0.2 & 0.0 & -0.1 & 0.0 \\
\hline Non-OECD other Asia & -0.1 & -0.3 & 0.1 & -0.3 & 0.2 & -0.1 & 0.0 & -0.2 & -0.5 & 0.3 & 0.0 & -0.1 & -0.1 \\
\hline China & 0.2 & -0.1 & 0.1 & -0.1 & 0.2 & 0.0 & -0.1 & -0.1 & 0.2 & 0.0 & -0.1 & 0.1 & 0.0 \\
\hline India & -0.1 & 0.0 & 0.0 & -0.1 & 0.0 & 0.0 & 0.0 & 0.0 & -0.1 & 0.0 & 0.0 & 0.0 & 0.0 \\
\hline Other & -0.2 & -0.2 & 0.0 & -0.1 & 0.0 & -0.1 & 0.1 & -0.1 & -0.6 & 0.2 & 0.0 & -0.1 & -0.1 \\
\hline Other & 0.0 & -0.4 & -0.4 & -0.4 & -0.1 & -0.4 & 0.1 & 0.1 & -0.9 & 0.4 & -0.9 & -0.2 & -0.1 \\
\hline
\end{tabular}

1. Simple average.

Source: Calculations based on OECD (2014), International Trade by Commodity Statistics (ITCS Database), May. 
ECO/WKP(2015)4

Table A2.5. Breakdown of the product structure effect by industry and technology intensity

Percentage points

\begin{tabular}{|c|c|c|c|c|c|c|c|c|c|c|c|c|c|}
\hline & \multirow{2}{*}{2003} & \multirow{2}{*}{2004} & \multirow{2}{*}{2005} & \multirow{2}{*}{2006} & \multirow{2}{*}{2007} & \multirow{2}{*}{2008} & \multirow{2}{*}{2009} & \multirow{2}{*}{2010} & \multirow{2}{*}{2011} & \multirow{2}{*}{2012} & \multicolumn{3}{|c|}{ Average $^{1}$} \\
\hline & & & & & & & & & & & $1996-2001$ & 002-07 & 2008-12 \\
\hline TOTAL & 0.8 & -1.0 & -0.3 & -0.8 & 2.3 & 0.6 & -1.2 & -0.2 & -2.9 & 3.5 & -0.4 & 0.5 & 0.0 \\
\hline Agriculture, forestry and fishing & 0.2 & -0.4 & 0.2 & -0.1 & -0.2 & -0.1 & 0.8 & -0.3 & -0.6 & 0.1 & -0.1 & 0.0 & 0.0 \\
\hline Manufacturing ${ }^{2}$ & 0.7 & -0.7 & -0.5 & -0.6 & 2.5 & 0.7 & -2.0 & 0.1 & -2.3 & 3.5 & -0.3 & 0.5 & 0.0 \\
\hline High-technology industries & 0.5 & 0.1 & 0.2 & 0.0 & 2.4 & 0.9 & -0.6 & -0.3 & -0.7 & 0.8 & -0.5 & 0.6 & 0.0 \\
\hline Aircraft and spacecraft & 0.2 & 0.1 & 0.0 & 0.0 & 0.0 & 0.0 & 0.1 & 0.0 & 0.0 & 0.1 & -0.1 & 0.1 & 0.0 \\
\hline Pharmaceuticals & 0.0 & 0.0 & 0.0 & 0.0 & 0.0 & 0.0 & 0.2 & -0.1 & -0.3 & 0.1 & 0.0 & 0.0 & 0.0 \\
\hline Office, accounting and computing machinery & 0.2 & 0.2 & 0.1 & 0.2 & 1.5 & 0.4 & -0.1 & 0.0 & -0.5 & 0.4 & -0.1 & 0.4 & 0.0 \\
\hline Radio, TV and communications equipment & 0.3 & -0.1 & 0.2 & -0.2 & 0.7 & 0.5 & -0.5 & -0.2 & -0.1 & 0.5 & -0.2 & 0.1 & 0.0 \\
\hline Medical, precision and optical instruments & -0.1 & -0.1 & -0.1 & 0.0 & 0.2 & 0.0 & -0.3 & 0.0 & 0.2 & -0.3 & -0.1 & 0.0 & -0.1 \\
\hline Medium-high-technology industries & -0.2 & -0.6 & -0.4 & -0.4 & -0.5 & -0.9 & -1.2 & 1.0 & -1.5 & 2.0 & 0.2 & -0.2 & -0.1 \\
\hline Other electrical machinery and apparatus & 0.0 & 0.0 & 0.0 & 0.0 & 0.0 & 0.0 & 0.0 & 0.0 & 0.0 & 0.0 & 0.0 & 0.0 & 0.0 \\
\hline Motor vehicles, trailers and semi-trailers & -0.1 & -0.5 & -0.3 & -0.5 & 0.4 & -0.7 & -1.4 & 1.2 & -1.4 & 1.4 & 0.1 & 0.0 & -0.2 \\
\hline Chemicals excluding pharmaceuticals & -0.1 & -0.1 & -0.1 & 0.0 & 0.0 & -0.1 & 0.1 & -0.1 & -0.2 & 0.1 & 0.0 & 0.0 & 0.0 \\
\hline Railroad equipment and other transport equipment & 0.0 & 0.0 & 0.0 & 0.0 & 0.0 & 0.0 & 0.0 & 0.0 & 0.0 & 0.1 & 0.0 & 0.0 & 0.0 \\
\hline Other machinery and equipment & 0.0 & -0.1 & 0.0 & 0.0 & -0.8 & 0.0 & 0.2 & 0.0 & 0.1 & 0.4 & 0.1 & -0.2 & 0.1 \\
\hline Medium-low-technology industries & 0.0 & -0.1 & 0.0 & -0.3 & 0.3 & 0.3 & -0.4 & -0.2 & 0.4 & 0.0 & -0.1 & 0.0 & 0.0 \\
\hline Building and repairing of ships and boats & 0.0 & 0.1 & 0.0 & 0.1 & 0.2 & 0.1 & -0.2 & 0.0 & 0.0 & 0.2 & 0.0 & 0.1 & 0.0 \\
\hline Rubber and plastics products & 0.0 & 0.0 & 0.0 & 0.0 & 0.0 & 0.0 & 0.0 & 0.0 & 0.1 & 0.0 & 0.0 & 0.0 & 0.0 \\
\hline Other non-metallic mineral products & 0.0 & 0.0 & 0.0 & 0.0 & 0.0 & 0.0 & 0.0 & -0.1 & 0.2 & -0.1 & -0.1 & 0.0 & 0.0 \\
\hline Basic metals and fabricated metal products & 0.0 & -0.1 & 0.0 & -0.4 & 0.0 & 0.2 & -0.2 & -0.1 & 0.1 & -0.1 & 0.0 & -0.1 & 0.0 \\
\hline Low-technology industries & 0.3 & -0.1 & -0.2 & 0.0 & 0.3 & 0.4 & 0.2 & -0.4 & -0.6 & 0.7 & 0.0 & 0.1 & 0.1 \\
\hline Other manufacturing and recycling & 0.1 & 0.0 & -0.1 & 0.1 & -0.1 & -0.1 & -0.1 & 0.0 & -0.4 & 0.1 & 0.0 & 0.0 & -0.1 \\
\hline Wood, pulp, paper and printing products & 0.1 & -0.1 & -0.1 & 0.0 & 0.0 & 0.0 & 0.0 & 0.0 & 0.0 & 0.0 & 0.0 & 0.0 & 0.0 \\
\hline Food products, beverages and tobacco & 0.2 & -0.2 & -0.1 & -0.1 & 0.3 & 0.3 & 0.3 & -0.3 & -0.2 & 0.4 & 0.0 & 0.0 & 0.1 \\
\hline Textiles, textile products, leather and footwear & 0.0 & 0.1 & 0.1 & 0.0 & 0.0 & 0.1 & 0.0 & 0.0 & 0.0 & 0.2 & 0.0 & 0.0 & 0.1 \\
\hline
\end{tabular}

1. Simple average.

2. Energy related industries are excluded; they would generally be included with medium-low-technology industries.

Source: Calculations based on OECD (2014), International Trade by Commodity Statistics (ITCS Database), May. 
Table A2.6. Breakdown of the geographical structure effect by partner country

Percentage points

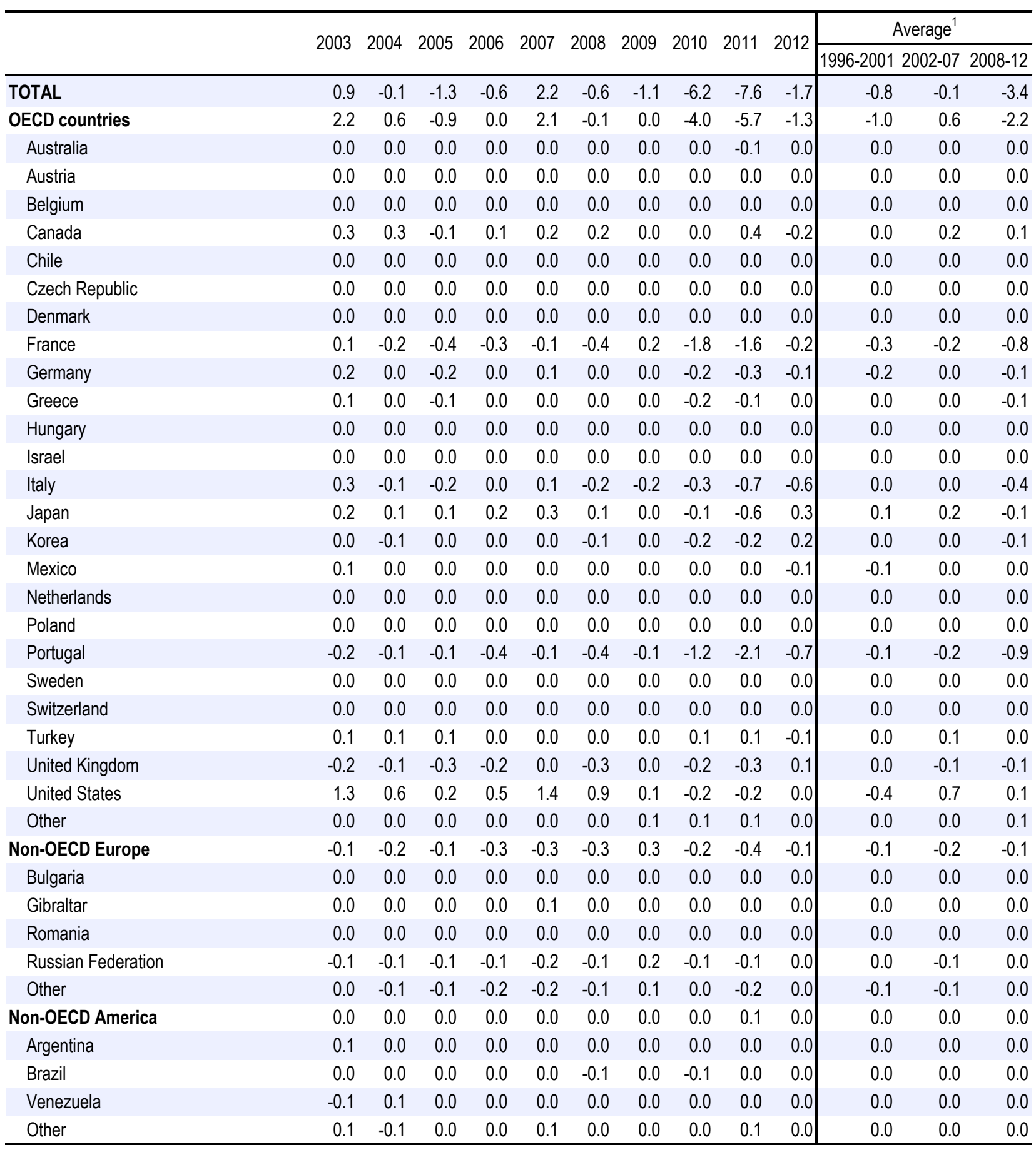


ECO/WKP(2015)4

Table A2.6. Breakdown of the geographical structure effect by partner country (continued)

Percentage points

\begin{tabular}{|c|c|c|c|c|c|c|c|c|c|c|c|c|c|}
\hline & \multirow{2}{*}{2003} & \multirow{2}{*}{2004} & \multirow{2}{*}{2005} & \multirow{2}{*}{2006} & \multirow{2}{*}{2007} & \multirow{2}{*}{2008} & \multirow{2}{*}{2009} & \multirow{2}{*}{2010} & \multirow{2}{*}{2011} & \multirow{2}{*}{2012} & \multicolumn{3}{|c|}{ Average $^{1}$} \\
\hline & & & & & & & & & & & \begin{tabular}{|c|}
$1996-20012$ \\
\end{tabular} & $22-07$ & $2008-12$ \\
\hline Africa & 0.0 & 0.0 & 0.0 & -0.1 & 0.3 & 0.2 & 0.1 & -0.3 & -0.2 & 0.1 & $\overline{0.0}$ & 0.1 & 0.0 \\
\hline Algeria & 0.0 & 0.0 & 0.0 & -0.1 & 0.1 & 0.1 & 0.1 & -0.2 & -0.1 & 0.1 & 0.0 & 0.0 & 0.0 \\
\hline Egypt & 0.0 & 0.0 & 0.0 & 0.0 & 0.0 & 0.0 & 0.0 & 0.0 & 0.0 & 0.0 & 0.0 & 0.0 & 0.0 \\
\hline Morocco & 0.0 & 0.0 & 0.0 & 0.0 & 0.2 & 0.1 & 0.0 & -0.2 & 0.0 & 0.0 & 0.0 & 0.1 & 0.0 \\
\hline South Africa & 0.0 & 0.0 & 0.0 & 0.0 & 0.0 & 0.0 & 0.0 & 0.0 & 0.0 & 0.0 & 0.0 & 0.0 & 0.0 \\
\hline Tunisia & 0.0 & 0.0 & 0.0 & 0.0 & 0.0 & 0.0 & 0.0 & 0.0 & -0.1 & 0.0 & 0.0 & 0.0 & 0.0 \\
\hline Other & 0.0 & 0.0 & 0.0 & 0.0 & 0.0 & -0.1 & 0.0 & 0.0 & 0.0 & 0.0 & 0.0 & 0.0 & 0.0 \\
\hline Non-OECD Near and Middle East Asia & -0.1 & 0.0 & -0.1 & -0.1 & -0.2 & -0.2 & -0.1 & 0.2 & 0.0 & 0.0 & 0.0 & -0.1 & 0.0 \\
\hline Saudi Arabia & 0.0 & 0.0 & 0.0 & 0.0 & 0.0 & 0.0 & 0.0 & 0.0 & 0.0 & 0.0 & 0.0 & 0.0 & 0.0 \\
\hline United Arab Emirates & -0.1 & 0.0 & -0.1 & 0.0 & -0.1 & -0.1 & 0.0 & 0.1 & -0.1 & 0.0 & 0.0 & 0.0 & 0.0 \\
\hline Other & 0.0 & 0.0 & 0.0 & 0.0 & -0.1 & -0.1 & -0.1 & 0.1 & 0.1 & 0.0 & 0.0 & 0.0 & 0.0 \\
\hline Non-OECD other Asia & -1.1 & -0.5 & -0.2 & -0.2 & 0.4 & 0.0 & -1.3 & -1.8 & -1.4 & -0.5 & 0.2 & -0.4 & -1.0 \\
\hline China & -0.9 & -0.3 & -0.2 & -0.2 & 0.2 & 0.1 & -0.7 & -0.8 & 1.0 & -0.8 & -0.1 & -0.3 & -0.3 \\
\hline India & -0.1 & -0.1 & -0.1 & -0.1 & -0.2 & -0.1 & -0.1 & -0.1 & -0.1 & 0.2 & 0.0 & -0.1 & 0.0 \\
\hline Other & -0.2 & -0.1 & 0.2 & 0.1 & 0.4 & 0.1 & -0.5 & -0.9 & -2.3 & 0.2 & 0.3 & 0.0 & -0.7 \\
\hline Other & 0.0 & 0.0 & 0.2 & 0.1 & -0.1 & -0.1 & 0.0 & 0.0 & -0.1 & 0.1 & 0.0 & 0.0 & 0.0 \\
\hline
\end{tabular}

1. Simple average.

Source: Calculations based on OECD (2014), International Trade by Commodity Statistics (ITCS Database), May. 
ECO/WKP(2015)4

\section{WORKING PAPERS}

The full series of Economics Department Working Papers can be consulted at www.oecd.org/eco/workingpapers

1185. Raising the economic participation of women in India - a new growth engine?

(Februrary 2015) by Piritta Sorsa

1184. Improving health outcomes and health care in India

(January 2015) by Isabelle Joumard and Ankit Kumar

1183. Challenges and opportunities of India's manufacturing sector

(January 2015) by Isabelle Joumard, Urban Sila and Hermes Morgavi

1182. The heterogeneity of product market regulations

(December 2014) by Jean-Marc Fournier

1181. Implicit regulatory barriers in the EU single market: new empirical evidence from gravity models

(December 2014) by Jean-Marc Fournier, Aurore Domps, Yaëlle Gorin, Xavier Guillet and

Délia Morchoisne

1180. Can pro-growth policies lift all boats? An analysis based on household disposable income

(December 2014) by Orsetta Causa, Alain de Serres and Nicolas Ruiz

1179. Empirical evidence on the effects of environmental policy stringency on productivity growth (December 2014) by Silvia Albrizio, Tomasz Koźluk and Vera Zipperer

1178. The Indicators of the Economic Burdens of Environmental Policy Design - Results from the OECD Questionnaire

(December 2014) by Tomasz Koźluk

1177. Measuring Environmental Policy Stringency in OECD Countries-A Composite Index Approach (December 2014) by Enrico Botta and Tomasz Koźluk

1176. Do Environmental Policies Matter for Productivity Growth? Insights from new Cross-Country Measures of Environmental Policies

(December 2014) by Silvia Albrizio, Enrico Botta, Tomasz Koźluk and Vera Zipperer

1175. Making economic growth more socially inclusive

(December 2014) by Andrés Fuentes Hutfilter and Andreas Kappeler

1174. New tax and expenditure elasticity estimates for EU budget surveillance

(December 2014) by Robert W.R. Price, Thai-Thanh Dang and Yvan Guillemette

1173. Moving towards a more dynamic business sector in Spain

(November 2014) by Alberto Gonzalez Pandiella

1172. Better harnessing talent and knowledge to boost sustainable medium-growth in Spain

(November 2014) by David Haugh and Ben Westmore

1171. The internet economy - regulatory challenges and practices 
(November 2014) by Isabell Koske, Rosamaria Bitetti, Isabelle Wanner and Ewan Sutherland

1170. A revival of the private rental sector of the housing market? Lessons from Germany, Finland, the Czech Republic and the Netherlands

(October 2014) by Rik de Boer and Rosamaria Bitetti

1169. Secular stagnation: evidence and implications for economic policy

(October 2014) by Łukasz Rawdanowicz, Romain Bouis, Kei-Ichiro Inaba and

Ane Kathrine Christensen

1168. Investment gaps after the crisis

(October 2014) by Christine Lewis, Nigel Pain, Jan Strasky and Fusako Menkyna

1167. Factors behind the decline in real long-term government bond yield

(October 2014) by Romain Bouis, Kei-Ichiro Inaba, Łukasz Rawdanowicz and

Ane Kathrine Christensen

1166. The effect of the global financial crisis on the OECD potential output

(October 2014) by Patrice Ollivaud and David Turner

1165. Determinants of households' investment in energy efficiency and renewables - evidence from the OECD Survey on household environmental behaviour and attitudes

(October 2014) by Nadia Ameli and Nicola Brandt

1164. Addressing high household debt in Korea

(September 2014) by Randall S. Jones and Myungkyoo Kim

1163. Reducing the high rate of poverty among the elderly in Korea

(September 2014) by Randall S. Jones and Satoshi Urasawa

1162. Promoting the financing of SMEs and start-ups in Korea

(September 2014) by Randall S. Jones and Myungkyoo Kim

1161. Fostering inclusive growth by promoting structural change in the business sector

(September 2014) by Rauf Gönenç, Oliver Röhn, Vincent Koen and Fethi Öğünç

1160. Reducing macroeconomic imbalances in Turkey

(September 2014) by Oliver Röhn, Rauf Gönenç, Vincent Koen and Evren Erdoğan Coşar

1159. Reinvigorating the EU Single Market

(September 2014) by Jean-Marc Fournier.

1158. An exploration of the determinants of the subjective well-being of Americans during the great recession

(August 2014) by Aida Caldera Sánchez and Caroline Tassot.

1157. Boosting the development of efficient SMEs in the Netherlands

(September) by Rafał Kierzenkowski and Jochebed Kastaneer

1156. Making the banking sector more resilient and reducing household debt in the Netherlands (September 2014) by Rafał Kierzenkowski, Olena Havrylchyk and Pierre Beynet 